\title{
Stunting and its associated factors among 6-7-year-old children in southern Iran: a nested case-control study
}

\author{
Mohammad Javad Fatemi ${ }^{1}$, Mohammad Fararouei ${ }^{2, *}$, Hossein Moravej ${ }^{3}$ and \\ Mostafa Dianatinasab ${ }^{4}$ \\ ${ }^{1}$ Student Research Committee, Center for Health Sciences, Department of Epidemiology, School of Health, Shiraz \\ University of Medical Sciences, Shiraz, Islamic Republic of Iran: ${ }^{2}$ Department of Epidemiology, Faculty of Public \\ Health, Shiraz University of Medical Sciences, Shiraz, Islamic Republic of Iran: ${ }^{3}$ Research Center for Health Sciences, \\ Department of Pediatrics, School of Medicine, Shiraz University of Medical Sciences, Shiraz, Islamic Republic of Iran: \\ ${ }^{4}$ Center for Health Related Social and Behavioral Sciences Research, Shahroud University of Medical Sciences, \\ Shahroud, Islamic Republic of Iran
}

Submitted 29 November 2017: Final revision received 1 July 2018: Accepted 5 September 2018: First published online 15 0ctober 2018

\begin{abstract}
Objective: Height-for-age shorter than 3th percentile or 2 SD below the median of the National Center for Health Statistics/WHO growth reference is known as stunting. The present study aimed to measure the association of several factors with stunting in a cohort born from 2009 to 2010 in Shiraz, Iran.

Design/Setting/Subjects: Nested case-control study conducted on pre-school children in 2016. Participants were 200 children suffering from stunting (case group) and 200 children with normal height (control group).

Results: Results of multivariable logistic regression analysis suggested a significant relationship (adjusted OR; 95\% CI) between stunting and mother's occupation (employed $v$. housewife: $3.58 ; 1.73,7.39$ ) and chronic diseases (yes $v$. no: 2.93; $1 \cdot 25,6 \cdot 88)$. In addition, significant associations were found between family income (<10 million $v .>30$ million Rials: $5 \cdot 63 ; 2 \cdot 46,12 \cdot 87$ ), diary consumption (very little $v$. high: $5.93 ; 1 \cdot 74,20 \cdot 18$ ) and animal protein in diet (low $v$. very high: $2 \cdot 42 ; 1.13$, 5.19) and stunting among children. Also, chance of stunting was inversely associated with birth interval ( $<2$ years $v$. first child: $3 \cdot 13 ; 1.45,6 \cdot 76)$ and duration of exclusive breast-feeding (18-24 months $v$. formula only or breast-feeding for $<18$ months: 0.53 ; $0.30,0.92$ ).

Conclusions: Mothers being housewife, possibly due to having more time to take care of their children, childhood diseases and consumption of dairy foods are strong and modifiable factors which can positively affect Iranian children's stature. Higher family income is another important factor in stunting but under less parental control.
\end{abstract}

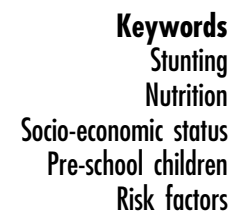

Stunting

lutrition

socio-economic status

Risk factors
Anthropometric measures during early life and childhood are among the most useful parameters for assessing children's health ${ }^{(1,2)}$. In particular, weight and height are most widely used to assess many aspects of children's health and nutritional status ${ }^{(2,3)}$. Growth indices are associated with the risk of morbidity, mortality, and cognitive and even behavioural status ${ }^{(2,4-7)}$. In that regard, growth charts are provided and used as effective tools for determining and assessing children's growth ${ }^{(8)}$. Of these two indices of physical growth, height is considered a more stable indicator for health status as it represents longer health conditions compared with weight, which represents current or acute health conditions. Although there is no universally accepted definition for short linear growth, in many cases height-for-age shorter than the 3th percentile or $2 \mathrm{sD}$ below the median of National Center for Health Statistics (NCHS)/WHO growth reference (WHO, 1995) is considered stunting ${ }^{(1)}$. Although stunting is a frequent health problem among children throughout the world, the condition is much worse in developing countries as it has been estimated that more than $50 \%$ of children under 5 years in several low-income countries suffer from stunting ${ }^{(3)}$. It is noted that growth is usually normal from birth to 3 or 6 months of age, with growth and development problems mostly appearing after this period ${ }^{(6)}$.

Every person is born with his/her own growth potential which is believed to be driven by genetic background. However, the hypothetical role of genetic diversity in 
children's growth between developed and developing countries is not supported by WHO, which is condemning the use of national growth standards. According to WHO, young children who are born and live under appropriate conditions will catch up with their maximum growth potential $^{(8,9)}$. Accordingly, other conditions including social and nutritional factors may also affect growth ${ }^{(6)}$. For example, the difference in linear growth between developed and developing countries is mostly attributed to socio-economic and nutritional factors rather than genetic diversity $^{(10)}$. However, it seems that the causes of stunting are unknown for a significant proportion of cases. As the result, a huge amount of effort is still ongoing to understand factors affecting stunting ${ }^{(1,6,10,11)}$. For example, while the results from several epidemiological studies suggest that dietary factors are the main contributors to stunting in developing countries ${ }^{(12)}$, not all the results are consistent ${ }^{(11)}$. In addition, based on the literature, it is hard to elucidate the effect of the timing of different environmental factors, including nutrition, on individual linear growth (i.e. before or during pregnancy or after birth) ${ }^{(13,14)}$.

Stunting is a health issue in Iran. For example, in a study on a representative sample of Iranian children and adolescents, $2 \cdot 6 \%$ of the study participants were diagnosed with short stature. Noticeably, the problem comes with a small geographical variation from less than $2 \%$ in provinces with the highest income to just more than $3 \%$ in lowest-income provinces. This finding suggests that socio-economic status has only a small effect on stunting among Iranian children ${ }^{(15)}$. The relatively low prevalence and low geographical variation of stunting in Iran may suggest the importance of factors other than socioeconomic status in the incidence of stunting. Considering the importance of stunting and its related lifelong side-effects, the aim of the present study was to measure the associations of study variables with stunting among 6-7-year-old children who had normal weight and height (taller than 20th percentile of the NCHS/WHO growth chart) at birth. As the result, the associated factors should affect growth after birth and not the pre-birth (perinatal or maternal) or pubertal period.

\section{Materials and methods}

\section{Setting}

The current nested case-control study was conducted in 2016 to investigate the factors associated with stunting among 400 children aged 6-7 years registered with Shiraz health-care centres. In Iran, each urban health centre is responsible for providing primary health and general medical care to the residents living within its defined geographical area. Among different services provided by these health centres, mother and child primary health care are fundamental. These services include maternity and pregnancy care, and children's vaccination and growth and development monitoring. As childhood vaccination is mandatory in Iran, it is believed that almost all children from birth to school age ( 7 years old) are registered with and immunized in the nearby health centres.

\section{Sampling}

Two-stage cluster sampling was conducted to select the required participants. For that purpose, health centres were considered clusters and, within each randomly selected centre, all cases and a random sample of controls were selected among eligible children. The total number of births registered with the health centres in Shiraz during 2009 to 2010 was about 27000 . Sampling started with obtaining a list of urban health centres $(n 78)$ from the deputy of health, Shiraz University of Medical Sciences, from which twenty-five health centres were selected randomly. The number of centres selected was defined to reach the required sample size of stunted children. Selected centres were visited by one of the research team members asking for a list of 6-7-year-old registered children. The family health files of the selected children were reviewed and the required information, including weight and height of the children from birth to the last visit, was extracted by a trained health nurse. The defined age range of the study population was selected to exclude pubertal growth from the study because puberty may occur as early as 9 years of age in some girls. Moreover, above age 9 years, children have no routine visits to the health centres and their anthropometric indices are no longer measured.

\section{Data collection}

A datasheet was used to extract data from the selected children's family health files, in which health and nutritional status of the child and sociodemographic information on the parents were recorded. The extracted information included child's sex, date of birth, child's key nutritional information including starting and ending dates of breast-feeding, starting date and types of complementary foods, immunization history, number of siblings, birth interval to the previous sibling, birth order of the child, mother's age at pregnancy of the selected child, anthropometric measures (weight and height) from birth to age 7 years, and parents' educational and occupational status. The health nurses used the anthropometric data to define children's growth status and provided a list of children with stunting for each centre. In addition, mothers of the selected children were contacted and the remaining information required was obtained via a telephone interview. The data collected via telephone interview included any medical condition the child was suffering from. In addition, dietary intake of the child including meat, dairy, fruit and vegetable consumption was obtained via the following questions: 'Regarding the duration between the 
time at which you stopped breast-feeding your child to date, generally how you describe the diet of your child with regard to the amount of each of the following foods: red and white meats, dairy products, fruits and vegetables?' For each of the above foods, the answer was on a 5-point Likert scale from 'almost nothing' to 'very high'. The latest job and educational status and total family income of the parents were also obtained from the mothers during the interview. The questionnaire was made and evaluated by an expert team consisting of an epidemiologist, a paediatrician and an experienced healthcare provider. At the start of the telephone interview, the mothers received a brief explanation about the research and verbal informed consent was obtained (approval number 9584). To control for psychological effects and recall bias in the reports from mothers, the participants were not told how and why they were selected (their child is a case or control).

The telephone interview was conducted by a female nurse using an interview-administered questionnaire. The participation rate to the telephone interview was very high (98\%; only four mothers of normal children were not able to participate due to not being available). The mothers who were not reached were replaced by mothers of children with normal height in the same centre. A pilot study on twenty-five normal and twenty-five stunted children was conducted prior to starting the main study to evaluate the methods of interview and the questionnaire's reliability. According to a test-retest analysis, the reliability of the questionnaire was considered good (Cronbach's $\alpha=0.78$ ). In the pilot phase of the study, questions regarding breast-feeding and complementary foods (also recorded in the family health file) were asked of the mothers and the collected information was compared with the data from the health files to check if reporting and recall biases (common type of biases in case-control studies) were an issue. No significant difference between the data from health files and those from the interview was observed in either group.

\section{Inclusion criteria}

All children were between 6 and 7 years of age, were born with height above the 20th percentile of the NCHS/WHO growth chart and were living with both parents based on the mother's report. No single-parent children were included due to the expected deep and complicated effects of missing parents on children's health.

\section{Exclusion criteria}

Children were excluded if their mother reported to have changed address as this could have caused significant alteration in the child's living and health conditions (e.g. moving from a rural area to the city during the participant's life). Children were also excluded if the mother reported, based on a physician's diagnosis, that the child was suffering from a condition known to affect children's growth (e.g. growth hormone deficiency).

\section{Selection of cases}

Stunting among children was defined according to the WHO. Children who were born with normal weight and height, but whose height was shorter than the 3rd percentile of their sex- and age-specific height of the NCHS/ WHO growth reference at the time of the study, were selected as cases.

\section{Selection of controls}

Controls were randomly selected, with the same sex ratio, from children who were registered at the same health centre as the stunted children (i.e. cases and controls were frequency matched for sex and health centre). Control children had height taller than the 20th percentile of their sex- and age-specific height of the NCHS/WHO growth reference at the time of the study.

\section{Sample size and statistical methods}

A sample size of 380 children (190 stunted participants as cases and 190 controls with normal height) was required to obtain a significant association between stunting and mother's job with $\mathrm{OR} \geq 2$. The type I error and power of the test were set to 5 and $80 \%$, respectively. However, considering the possibility of missing data, the number of participants was increased to 200 for each group. Accordingly, 400 children aged 6-7 years were selected. Their data were analysed using the statistical software package IBM SPSS Statistics version 19. Univariate analysis was conducted to calculate unadjusted associations using frequency distributions, means and simple logistic regression. Multiple logistic regression was applied to measure the adjusted associations between the study variables (listed above) and stunting. The final logistic model was defined using the stepwise selection strategy.

\section{Results}

The distribution of the study variables among the case and control groups is compared in Table 1 . In the case and control participants, 107 (53.50\%) and 105 (52.50\%) were female, respectively $(P=0 \cdot 85)$.

\section{Univariate analysis}

Unadjusted associations between stunting and each of the qualitative study variables were examined using simple logistic regression analysis and the results are presented in Table 2. Significant associations were found between the risk of stunting and father's job, mother's education, family income, birth interval, child's type of feeding during infancy, duration of breast-feeding, childhood diseases, 
Table 1 Characteristics of the study participants: children aged 6-7 years from Shiraz, southern Iran, 2016

\begin{tabular}{|c|c|c|c|c|c|}
\hline \multirow[b]{3}{*}{ Variable } & \multicolumn{4}{|c|}{ Frequency distribution } & \multirow[b]{3}{*}{$P$ value* } \\
\hline & \multicolumn{2}{|c|}{ Cases } & \multicolumn{2}{|c|}{ Controls } & \\
\hline & $n$ & $\%$ & $n$ & $\%$ & \\
\hline \multicolumn{6}{|l|}{ Sex } \\
\hline Female & 107 & 53.5 & 105 & 52.5 & \multirow[t]{2}{*}{0.842} \\
\hline Male & 93 & 46.5 & 95 & 47.5 & \\
\hline \multicolumn{6}{|l|}{ Father's job } \\
\hline Unemployed & 118 & $59 \cdot 0$ & 114 & $57 \cdot 0$ & \multirow[t]{4}{*}{0.003} \\
\hline Labour & 38 & $19 \cdot 0$ & 18 & 9.0 & \\
\hline Employee & 31 & 15.5 & 39 & 19.5 & \\
\hline Professional & 13 & 6.5 & 29 & 14.5 & \\
\hline \multicolumn{6}{|l|}{ Mother's job } \\
\hline Housewife & 167 & 83.5 & 177 & 88.5 & \multirow[t]{2}{*}{0.154} \\
\hline Employed & 33 & $16 \cdot 5$ & 23 & 11.5 & \\
\hline \multicolumn{6}{|l|}{ Family income (Rials) } \\
\hline$<10$ million & 37 & $18 \cdot 5$ & 16 & $8 \cdot 0$ & $<0.001$ \\
\hline 10-30 million & 129 & 64.5 & 111 & 55.5 & \\
\hline$>30$ million & 34 & $17 \cdot 0$ & 73 & 36.5 & \\
\hline Mother's education & & & & & \\
\hline Primary & 26 & 13.0 & 11 & 5.5 & 0.003 \\
\hline Secondary & 39 & 19.5 & 30 & $15 \cdot 0$ & \\
\hline High school and diploma & 101 & 50.5 & 100 & $50 \cdot 0$ & \\
\hline Academic & 34 & $17 \cdot 0$ & 59 & 29.5 & \\
\hline Father's education & & & & & \\
\hline Primary & 17 & 8.5 & 12 & $6 \cdot 0$ & 0.292 \\
\hline Secondary & 48 & 24.0 & 43 & 21.5 & \\
\hline High school and diploma & 96 & 48.0 & 91 & $45 \cdot 5$ & \\
\hline Academic & 39 & 19.5 & 54 & $27 \cdot 0$ & \\
\hline Birth interval & & & & & \\
\hline First child & 108 & $54 \cdot 0$ & 120 & $60 \cdot 0$ & 0.001 \\
\hline$<2$ years & 36 & $18 \cdot 0$ & 13 & 6.5 & \\
\hline $2-3$ years & 18 & 9.0 & 9 & 4.5 & \\
\hline$>3$ years & 38 & $19 \cdot 0$ & 58 & $29 \cdot 0$ & \\
\hline Type of food $†$ & & & & & \\
\hline Formula milk & 39 & 19.5 & 17 & 8.5 & 0.001 \\
\hline Both & 23 & 11.5 & 14 & $7 \cdot 0$ & \\
\hline Breast milk & 138 & 69.0 & 169 & 84.5 & \\
\hline Duration of breast-feeding & & & & & \\
\hline Formula only or breast feeding for $<18$ months & 51 & $25 \cdot 5$ & 28 & $14 \cdot 0$ & 0.013 \\
\hline $18-24$ months & 142 & 71.0 & 160 & $80 \cdot 0$ & \\
\hline$>24$ months & 7 & 3.5 & 12 & $6 \cdot 0$ & \\
\hline Birth order & & & & & \\
\hline First & 133 & $66 \cdot 5$ & 126 & 63.0 & 0.615 \\
\hline Second & 46 & $23 \cdot 0$ & 57 & $28 \cdot 5$ & \\
\hline Third & 16 & 8.0 & 13 & 6.5 & \\
\hline Fourth & 5 & 2.5 & 4 & $2 \cdot 0$ & \\
\hline Childhood disease & & & & & \\
\hline No & 177 & 88.5 & 189 & 94.5 & 0.031 \\
\hline Yes & 23 & 11.5 & 11 & 5.5 & \\
\hline Mother's age at pregnancy & & & & & \\
\hline$<20$ years & 25 & $12 \cdot 5$ & 21 & $10 \cdot 5$ & 0.283 \\
\hline $20-34$ years & 167 & 83.5 & 164 & $82 \cdot 0$ & \\
\hline$\geq 35$ years & 8 & 4.0 & 15 & 7.5 & \\
\hline Dairy products in diet & & & & & \\
\hline Very low & 17 & 8.5 & 4 & $2 \cdot 0$ & 0.001 \\
\hline Low & 32 & $16 \cdot 0$ & 18 & $9 \cdot 0$ & \\
\hline Average & 83 & 41.5 & 85 & 42.5 & \\
\hline High & 68 & 34.0 & 93 & $46 \cdot 5$ & \\
\hline Junk food consumption & & & & & \\
\hline Rare & 34 & $17 \cdot 0$ & 60 & $30 \cdot 0$ & 0.004 \\
\hline Sometimes & 35 & 17.5 & 42 & $21 \cdot 0$ & \\
\hline Often & 88 & 44.0 & 71 & 35.5 & \\
\hline Always & 43 & 21.5 & 27 & 13.5 & \\
\hline Animal protein in diet & & & & & \\
\hline Very low & 11 & 5.5 & 12 & $6 \cdot 0$ & 0.079 \\
\hline Low & 46 & 23.0 & 26 & $13 \cdot 0$ & \\
\hline High & 112 & $56 \cdot 0$ & 127 & 63.5 & \\
\hline Very high & 31 & $15 \cdot 5$ & 35 & 17.5 & \\
\hline
\end{tabular}




\begin{tabular}{|c|c|c|c|c|c|}
\hline \multirow[b]{3}{*}{ Variable } & \multicolumn{4}{|c|}{ Frequency distribution } & \multirow[b]{3}{*}{$P$ value* } \\
\hline & \multicolumn{2}{|c|}{ Cases } & \multicolumn{2}{|c|}{ Controls } & \\
\hline & $n$ & $\%$ & $n$ & $\%$ & \\
\hline \multicolumn{6}{|c|}{ Fruits and vegetables in diet } \\
\hline Very low & 9 & 4.5 & 8 & $4 \cdot 0$ & 0.941 \\
\hline Low & 48 & 24.0 & 45 & 22.5 & \\
\hline High & 88 & 44.0 & 87 & 43.5 & \\
\hline Very high & 55 & 27.5 & 60 & $30 \cdot 0$ & \\
\hline
\end{tabular}

*Based on $x^{2}$ test.

†From birth to 2 years of age.

consumption of dairy products and consumption of foods with low nutritional value (i.e. junk foods; $P<0.05$ ).

\section{Multivariable analysis}

After reaching the final model and checking for potential interactions between the explanatory variables, the multiple logistic regression results (Table 2 ), which are presented as adjusted OR (AOR) and their 95\% CI, revealed significant relationships between the risk of stunting and mother's occupation (employed $v$. housewife: $\mathrm{AOR}=3.58$; $95 \%$ CI $1.73,7.39, P=0.001)$ and family income $(<10$ million $v$. $>30$ million Rials: $\mathrm{AOR}=5 \cdot 63$; $95 \%$ CI $2 \cdot 46$, 12.87, $P<0 \cdot 001)$. Significant associations were also found between stunting and duration of breast-feeding (18-24 months $v$. formula only or breast-feeding for <18 months: $\mathrm{AOR}=0.53 ; 95 \%$ CI 0.30, 0.92, $P=0.03$ ), birth interval ( $<2$ years $v$. first child: $\mathrm{AOR}=3 \cdot 13$; CI $95 \%$ $1.45,6.76, P=0.004$ ), childhood diseases (yes $v$. no: $\mathrm{AOR}=2 \cdot 93 ; 95 \% \mathrm{CI} 1 \cdot 25,6 \cdot 88, P=0 \cdot 013)$, use of dairy products (very little $v$. high: $\mathrm{AOR}=5.93 ; 95 \% \mathrm{CI} 1.74$, $20 \cdot 18, P=0 \cdot 004$ ) and animal protein in the diet (low $v$. very high: $\mathrm{AOR}=2 \cdot 42 ; 95 \% \mathrm{CI} 1 \cdot 13,5 \cdot 19, P=0 \cdot 022)$.

\section{Discussion}

The present population-based nested case-control study aimed to determine associated factors of stunting among 6-7-year-old children born with normal birth weight and height in Shiraz, Iran. The results indicated a significant relationship between stunting and mother's occupation, family income, birth interval, duration of breast-feeding, childhood diseases, consumption of dairy products and consumption of animal protein-based foods. However, no significant relationship was observed between sex and stunting. This finding is consistent with what was suggested in a critical review $^{(16)}$ and a national study in Iran ${ }^{(17)}$. The same conclusion was also made by Nojomi et al., who suggested no significant association between sex and stunting ${ }^{(18)}$. In contrast, a few studies conducted in Nepal showed a significant relationship between stunting and $\operatorname{sex}^{(19)}$. The contradiction between the results of the present study and the studies from Nepal may suggest social and cultural differences such as economy and sexual discrimination between communities. The current study introduced mother's involvement in the child's care as the strongest factor preventing stunting. Employed mothers, due to shortage of time during the day, use nursery services to take care of their children. In nurseries, children are not only more exposed to a wide variety of infections but they also receive less attention to their psychological and physiological needs. In fact, although malnutrition is suggested to be the most common threat to children's survival and health, it seems that the mother's presence in the family and her involvement in the child's care is getting less attention than it deserves. The results of the present study suggested that children with employed mothers had a higher risk of stunting irrespective of family income. Indeed, families with employed women are expected to have higher income. Thus, the negative effect of mother's employment on child growth is considerable. This also supports the hypothesis that employed mothers need more time to spend with their family and take care of their young children. Similar results were also obtained in a study from South Africa ${ }^{(20)}$ suggesting a negative impact of mother's employment on child growth. However, a retrospective cohort study in another city of Iran reported no association between mother's employment and growth failure among children under 2 years $^{(21)}$. On the other hand, another crosssectional study on Iranian children found a significant association between mother's employment and the risk of stunting among children aged 3-6 years ${ }^{(22)}$. It is worth noticing that neither of the above studies considered the height of children at birth. The findings of the present study also revealed a significant and adverse relationship between family income and stunting. This finding agrees with the results of several studies including those performed by Holakoei et al. and Mohammadpoorasl et al. ${ }^{(23,24)}$. This might be attributed to the fact that families with higher income have better access to quality foods and better living conditions. A study on children younger than 5 years of age showed that Iranian children were shorter than their counterparts in the USA. Indeed, the difference was more apparent in children under 1 year but it 
Table 2 Crude and adjusted associations of the study variables with risk of stunting among 6-7-year-old children from Shiraz, southern Iran, 2016

\begin{tabular}{|c|c|c|c|c|c|c|}
\hline \multirow[b]{2}{*}{ Variable } & \multicolumn{3}{|c|}{ Crude } & \multicolumn{3}{|c|}{ Adjusted } \\
\hline & OR & $95 \% \mathrm{Cl}$ & $P$ value & OR & $95 \% \mathrm{Cl}$ & $P$ value \\
\hline \multicolumn{7}{|l|}{ Sex } \\
\hline Female & 1.00 & Ref. & 0.841 & NR & - & - \\
\hline Male & 0.96 & $0.64,1.42$ & - & NR & - & - \\
\hline \multicolumn{7}{|l|}{ Father's job } \\
\hline Unemployed & 1.00 & Ref. & - & NR & - & - \\
\hline Labour & 2.04 & $1 \cdot 10,3 \cdot 71$ & 0.025 & NR & - & - \\
\hline Employee & 0.76 & $0.44,1.30$ & 0.330 & NR & - & - \\
\hline Professional & 0.43 & $0.21,0.87$ & 0.026 & NR & - & - \\
\hline \multicolumn{7}{|l|}{ Mother's job } \\
\hline Housewife & 1.00 & Ref. & - & 1.00 & Ref. & - \\
\hline Employed & 1.52 & $0.85,2.69$ & $0 \cdot 153$ & 3.58 & $1.73,7.39$ & 0.001 \\
\hline \multicolumn{7}{|l|}{ Family income (Rials) } \\
\hline$<10$ million & 4.96 & $2 \cdot 43,10 \cdot 13$ & $<0.001$ & 5.63 & $2 \cdot 46,12 \cdot 87$ & 0.001 \\
\hline 10-30 million & 2.49 & $1.54,4.03$ & $<0.001$ & 3.77 & $2 \cdot 09,6.79$ & 0.001 \\
\hline$>30$ million & 1.00 & Ref. & - & 1.00 & Ref. & - \\
\hline \multicolumn{7}{|l|}{ Mother's education } \\
\hline Primary & 1.00 & Ref. & _- & NR & - & - \\
\hline Secondary & 0.55 & $0.23,1.28$ & 0.162 & NR & - & - \\
\hline High school and diploma & 0.42 & $0.20,0.91$ & 0.028 & NR & - & - \\
\hline Academic & 0.24 & $0.10,0.55$ & $<0.001$ & NR & - & - \\
\hline \multicolumn{7}{|l|}{ Father's education } \\
\hline Primary & 1.00 & Ref. & _- & NR & - & - \\
\hline Secondary & 0.78 & $0.33,1.83$ & 0.582 & NR & - & - \\
\hline High school and diploma & 0.74 & $0.33,1.64$ & 0.464 & NR & - & - \\
\hline Academic & 0.51 & $0.21,1.18$ & 0.113 & NR & - & - \\
\hline \multicolumn{7}{|l|}{ Birth interval } \\
\hline First child & 1.00 & Ref. & - & 1.00 & Ref. & - \\
\hline$<2$ years & 3.07 & $1.55,6 \cdot 10$ & $<0.001$ & 3.13 & $1 \cdot 45,6 \cdot 76$ & 0.004 \\
\hline $2-3$ years & $2 \cdot 22$ & $0.95,5.15$ & 0.063 & $2 \cdot 12$ & $0.86,5.23$ & 0.102 \\
\hline$>3$ years & 0.72 & $0.44,1.18$ & 0.195 & 0.73 & $0.43,1.26$ & 0.263 \\
\hline \multicolumn{7}{|l|}{ Type of food* } \\
\hline Formula milk & 1.00 & - & - & NR & - & - \\
\hline Both & 0.71 & $0.29,1.71$ & 0.457 & NR & - & - \\
\hline Breast milk & 0.35 & $0.19,0.65$ & $<0.001$ & NR & - & - \\
\hline \multicolumn{7}{|l|}{ Duration of breast-feeding } \\
\hline Formula only or breast-feeding for $<18$ months & 1.00 & Ref. & - & 1.00 & Ref. & - \\
\hline $18-24$ months & 0.48 & $0.29,0.81$ & 0.006 & 0.53 & $0.30,0.92$ & 0.030 \\
\hline$>24$ months & 0.32 & $0.11,0.90$ & 0.032 & 0.43 & $0.14,1.36$ & 0.151 \\
\hline Birth order & & & & & & \\
\hline First & 1.00 & Ref. & - & NR & - & - \\
\hline Second & 0.76 & $0.48,1.20$ & 0.253 & NR & - & - \\
\hline Third & $1 \cdot 16$ & $0.53,2.52$ & 0.695 & NR & - & - \\
\hline Fourth & $1 \cdot 18$ & $0.31,4.51$ & 0.802 & NR & - & - \\
\hline Childhood disease & & & & & & \\
\hline No & 1.00 & Ref. & - & 1.00 & Ref. & - \\
\hline Yes & 2.23 & $1.05,4.73$ & 0.035 & 2.93 & $1 \cdot 25,6 \cdot 88$ & 0.013 \\
\hline Mother's age at pregnancy & & & & & & \\
\hline$<20$ years & 1.00 & Ref. & - & NR & - & - \\
\hline $20-34$ years & 0.85 & $0.46,1.58$ & 0.624 & NR & - & - \\
\hline$\geq 35$ years & 0.44 & $0.15,1.26$ & 0.126 & NR & - & - \\
\hline Dairy products in diet & & & & & & \\
\hline Very low & $5 \cdot 81$ & $1.87,18.05$ & 0.002 & 5.93 & $1 \cdot 74,20 \cdot 18$ & 0.004 \\
\hline Low & 2.43 & $1 \cdot 26,4 \cdot 68$ & 0.008 & 2.93 & $1.42,6.05$ & 0.003 \\
\hline Average & 1.33 & $0.86,2.06$ & $0 \cdot 198$ & 1.51 & $0.92,2.48$ & 0.092 \\
\hline High & 1.00 & Ref. & - & 1.00 & Ref. & - \\
\hline Junk food consumption & & & & & & \\
\hline Rare & 1.00 & Ref. & - & NR & - & - \\
\hline Sometimes & 1.47 & $0.79,2.72$ & 0.213 & NR & - & - \\
\hline Often & $2 \cdot 18$ & $1.29,3.69$ & 0.003 & NR & - & - \\
\hline Always & $2 \cdot 81$ & $1.48,5.32$ & 0.002 & NR & - & - \\
\hline Animal protein in diet & & & & & & \\
\hline Very low & 1.03 & $0.40,2.67$ & 0.948 & 0.68 & $0.22,2.05$ & 0.493 \\
\hline Low & 1.99 & $1.01,3.95$ & 0.043 & 2.42 & $1 \cdot 13,5 \cdot 19$ & 0.022 \\
\hline High & 0.99 & $0.57,1.71$ & 0.980 & 1.15 & $0 \cdot 62,2 \cdot 13$ & 0.640 \\
\hline Very high & 1.00 & Ref. & - & 1.00 & Ref. & - \\
\hline
\end{tabular}




\begin{tabular}{|c|c|c|c|c|c|c|}
\hline \multirow[b]{2}{*}{ Variable } & \multicolumn{3}{|c|}{ Crude } & \multicolumn{3}{|c|}{ Adjusted } \\
\hline & OR & $95 \% \mathrm{Cl}$ & $P$ value & OR & $95 \% \mathrm{Cl}$ & $P$ value \\
\hline \multicolumn{7}{|c|}{ Fruits and vegetables in diet } \\
\hline Very low & 1.00 & Ref. & - & NR & - & - \\
\hline Low & 0.94 & $0.33,2.67$ & 0.923 & NR & - & - \\
\hline High & 0.89 & $0.33,2.43$ & 0.835 & NR & - & - \\
\hline Very high & 0.81 & $0.29,2.26$ & 0.691 & NR & - & - \\
\hline
\end{tabular}

Ref., reference category; NR, not remaining in the final model.

All variables were included in the final model.

${ }^{*}$ From birth to 2 years of age.

diminished to some extent with age. In that study, the height of Iranian children living in families with high income was similar to that of US children. Moreover, rural children were found to be shorter than urban children ${ }^{(9)}$. This finding might be justified by the fact that nutrition and living conditions among rural families are not as good as those of families from cities ${ }^{(25)}$. Our study showed a significant and negative association between the duration of breast-feeding and risk of stunting. This finding is also supported by other studies inside and outside $\operatorname{Iran}^{(26,27)}$. Children's mean age at the time of cessation of breastfeeding varies from 7 to 30 months around the world, depending on the country's culture ${ }^{(28)}$. Generally, although breast-feeding is very important for mental and physical growth of the child, keeping the diet balanced as the child grows is even more important. The results of the current study indicated a significant relationship between chronic diseases among children and risk of stunting. Similar results were also reported from other studies performed on the same subject ${ }^{(29)}$. The results of our study also revealed a significant and direct relationship between diets with low dairy products and low animal protein and stunting. Although many believe that dairy products are important in children's growth ${ }^{(30,31)}$, others did not find any consistent association between consumption of these products and bone health indices among children ${ }^{(32)}$. Also regarding the consumption of animal protein and growth, several studies reported the same findings ${ }^{(33,34)}$.

According to the results of the present study, among urban families, family income and especially mother's involvement in childcare is among the most important factors. This is because urban families (compared with rural residents) in Iran are more able to provide basic nutritional needs to their children. In addition to family income and mother's presence at home, the current study introduced dairy products as a strong factor affecting stunting.

The present study was conducted on a sample of members of a 2008-2009 birth cohort in the biggest city in the southern part of Iran. As most of the required information was obtained from the children's health file, no or insignificant recall or information bias due to the casecontrol nature of the study was expected to occur. However, some nutritional and health-related information was asked from mothers in a telephone interview, which may cause some imprecision in reporting the events. In that regard, it is worth noticing that the responding mothers were not aware of the reason their child was selected (i.e. because of being stunted as a case or normal as a control). As a result, the bias due to the mother's reported information should be insignificant. Moreover, the overlapping health and nutritional information obtained from the family health file and the interview with the mother was compared and no significant difference was observed.

\section{Conclusion}

The results of current study reveal that stunting among Iranian children is an impairment with mostly very basic determinants, including socio-economic (employment of mother, family income), nutritional (breast-feeding, diary and animal protein consumption) and birth interval. These findings are practically very important as they confirm the importance of national family supportive policies in childcare and mother and child nutrition education programmes. In addition, the anthropometric indices of children with chronic diseases should be monitored as they may also face growth retardation in future.

\section{Acknowledgements}

Acknowledgements: The present study is a part of an MSc thesis written by M.J.F. under the supervision of M.F. The authors would like to thank Dr Tahamtan and Dr Farahbakhsh for their cooperation. They are also grateful for Ms A Keivanshekouh at the Research Improvement Center of Shiraz University of Medical Sciences for improving the English usage in the manuscript. Financial support: This work was supported by the Shiraz University of Medical Sciences (grant number 9584). The funder had no role in the design, analysis or writing of this article. Conflict of interest: The authors declare that there is no conflict of interest. Authorship: M.J.F. contributed to the design and implementation of the study, analysis and interpretation of the data, and was involved in drafting the manuscript. M.F. contributed to the design and implementation of the study, interpretation of the data, and was involved in drafting and revising the manuscript. H.M. 
contributed to the conception and design of the data and drafting the manuscript. M.D. contributed to the design and implementation of the study and was involved in drafting and revising the paper. All authors reviewed and approved the final version to be published. Ethics of buman subject participations: This study was conducted according to the guidelines laid down in the Declaration of Helsinki and all procedures involving human subjects were approved by the ethics committee of Shiraz University of Medical Sciences. Verbal informed consent was obtained from all subjects. Verbal consent was witnessed and formally recorded (approval number 9584).

\section{References}

1. Rogol AD \& Hayden GF (2014) Etiologies and early diagnosis of short stature and growth failure in children and adolescents. J Pediatr 164, 5 Suppl., S1-S14.e6.

2. Evazpoor A, Edalati A, Hyppönen E et al. (2016) Deaths of children aged under 5 years and related factors in the Islamic Republic of Iran: a population-based casecontrol study. East Mediterr Health J 22, 368-374.

3. Marriott BP, White A, Hadden L et al. (2012) World Health Organization (WHO) infant and young child feeding indicators: associations with growth measures in 14 low-income countries. Matern Child Nutr 8, 354-370.

4. Fararouei M, Brown I, Toori MA et al. (2013) Happiness and health behaviour in Iranian adolescent girls. J Adolesc 36, $1187-1192$.

5. Fararouei M, Robertson C, Whittaker J et al. (2010) Maternal $\mathrm{Hb}$ during pregnancy and offspring's educational achievement: a prospective cohort study over 30 years. Br J Nutr 104, 1363-1368.

6. Saenger P, Czernichow P, Hughes I et al. (2007) Small for gestational age: short stature and beyond. Endocr Rev 28, 219-251.

7. Hoddinott J, Behrman JR, Maluccio JA et al. (2013) Adult consequences of growth failure in early childhood. $\mathrm{Am} \mathrm{J}$ Clin Nutr 98, 1170-1178.

8. de Onis M, Onyango AW, Borghi E et al. (2007) Development of a WHO growth reference for school-aged children and adolescents. Bull World Health Organ 85, 660-667.

9. Rezaeian S, Ahmadzadeh J, Esmailnasab N et al. (2014) Assessment of health and nutritional status in children based on school screening programs. Health Scope 3, e14462.

10. Fink G, Sudfeld CR, Danaei G et al. (2014) Scaling-up access to family planning may improve linear growth and child development in low and middle income countries. PLoS One 9, e102391.

11. Hyppönen E, Fararouei M, Sovio U et al. (2011) High-dose vitamin D supplements are not associated with linear growth in a large Finnish cohort. J Nutr 141, 843-848.

12. Prendergast AJ \& Humphrey JH (2014) The stunting syndrome in developing countries. Paediatr Int Child Health 34, 250-265.

13. Millward DJ (2017) Nutrition, infection and stunting: the roles of deficiencies of individual nutrients and foods, and of inflammation, as determinants of reduced linear growth of children. Nutr Res Rev 30, 50-72.

14. Michaelsen KF (2015) 1.1 Child growth. In World Review of Nutrition and Dietetics. vol. 113: Pediatric Nutrition in Practice, 2nd ed., pp. 1-5 [B Koletzko, J Bhatia, ZA Bhutta et al., editors]. Basel: Karger Publishers.

15. Bahreynian M, Motlagh ME, Qorbani M et al. (2015) Prevalence of growth disorders in a nationally representative sample of Iranian adolescents according to socioeconomic status: the CASPIAN-III Study. Pediatr Neonatol 56, 242-247.

16. Visser-van Balen H Sinnema G et al. (2006) Growing up with idiopathic short stature: psychosocial development and hormone treatment; a critical review. Arch Dis Child 91, 433-439.

17. Saeidlou SN, Babaei F \& Ayremlou P (2014) Children malnutrition in northwestern, central and southern regions of Iran: does geographic location matter? Glob J Health Sci $\mathbf{6}$, issue 4, 36-41.

18. Nojomi N, Kafashi A \& Najmabadi S (2003) Study of frequency of malnutrition risk factors in under 5 years children in Karaj, 2001-2002. Razi J Med Sci 10, 123-130.

19. Pramod Singh G, Nair M, Grubesic RB et al. (2009) Factors associated with underweight and stunting among children in rural Terai of eastern Nepal. Asia Pac J Public Health 21, 144-152.

20. Mamabolo RL, Alberts M, Steyn NP et al. (2005) Prevalence and determinants of stunting and overweight in 3-year-old black South African children residing in the Central Region of Limpopo Province, South Africa. Public Health Nutr 8, 501-508.

21. Ebrahimzadeh F, Hajizadeh E, Baghestani AR et al. (2018) Effective factors on the rate of growth failure in children below two years of age: a recurrent events model. Iran $J$ Public Health 47, 418-426.

22. Maddah M, Mohtasham-Amiri Z, Rashidi A et al. (2007) Height and weight of urban preschool children in relation to their mothers' educational levels and employment status in Rasht City, northern Iran. Matern Child Nutr 3, 52-57.

23. Holakouie Naieni K, Fotouhi A, Borhani M et al. (2006) Risk factors for malnutrition in 6- to 30-months old children seen at health centers in Hormozgan Province.IJE 1, 27-32.

24. Mohammadpoorasl A, Sahebihag M, Rostami F et al. (2010) Factors related to undesirable growth of 6 month-2years old children in Tabriz-Iran. J Gorgan Univ Med Sci 12, 45-50.

25. Sheikholeslam R, Kimiagar M, Siasi F et al. (2004) Multidisciplinary intervention for reducing malnutrition among children in the Islamic Republic of Iran. East Mediterr Health J 10, 844-852.

26. Mohsenzande A, Mardani M \& Shahkarami K (2008) FE failure of exclusive breast feeding in first 6 months of life of infants referred to health centers of Khorramabad. Yafte 35, 55-62.

27. Martin RM, Smith GD, Mangtani P et al. (2002) Association between breast feeding and growth: the Boyd-Orr cohort study. Arch Dis Child Fetal Neonatal Ed 87, F193-F201.

28. Dettwyler KA (1995) A time to wean: the hominid blueprint for the natural age of weaning in modern human populations. In Breastfeeding. Biocultural Perspectives, pp. 39-74 [P Stuart-Macadam and KA Dettwyler, editors]. New York: Aldine de Gruyter.

29. Wamani H, Åstrøm AN, Peterson S et al. (2006) Predictors of poor anthropometric status among children under 2 years of age in rural Uganda. Public Health Nutr 9, 320-326.

30. Hegde ST \& Gaur A (2017) Spotlighting risk factors for severe acute malnutrition under 5 years: a case control study. J Pediatr Res 4, 140-144.

31. Sharifzadeh G, Mehrjoofard H \& Raghebi S (2010) Prevalence of malnutrition in under 6-year olds in South Khorasan, Iran. Iran J Pediatr 20, 435-441.

32. Lanou AJ, Berkow SE \& Barnard ND (2005) Calcium, dairy products, and bone health in children and young adults: a reevaluation of the evidence. Pediatrics 115, 736-743.

33. Hoppe C, Udam TR, Lauritzen L et al. (2004) Animal protein intake, serum insulin-like growth factor I, and growth in healthy 2.5-y-old Danish children. Am J Clin Nutr 80, $447-452$.

34. Marquis GS, Habicht J-P, Lanata CF et al. (1997) Breast milk or animal-product foods improve linear growth of Peruvian toddlers consuming marginal diets. Am J Clin Nutr 66, 1102-1109. 